\title{
Building a Nation, Building a Modern Capital City: A Comparative Study of Ankara's and Tirana's First Master Plans
}

\author{
Deniz Avc1 Hosanl $1{ }^{1}$ \\ ORCID: 0000-0003-1157-5654
}

\author{
Giuseppe Resta ${ }^{2}$ \\ ORCID: 0000-0001-8489-5291
}

\begin{abstract}
Two capital cities, Tirana and Ankara, once united under the Ottoman banner, shared a similar urban development process ideologically and physically as they were designated the new capital cities under disparate national banners in 1920 and 1923 respectively. After the disintegration of the Ottoman Empire, both cities witnessed a non-negligible transformation. Their urban development occurred in a congruent fashion including urban components and settlement patterns with a strong foreign influence, i.e., paid foreign technocrats for the case of Ankara, and the foreign fascist rulers for the case of Tirana. This article provided a comparative analysis of these two cities and their ideological and physical transformations via evaluation of their first urban development plans, i.e., Ankara's by Carl Christoph Lörcher and Tirana's by Gherardo Bosio, and ideological charges behind their implementations. The rise of new nationalist regimes employed urban planning as a tool to implement ideological modernization and nation-building agendas. The focus of the text was to correlate how the two modernist plans oscillated between a tabula-rasa approach and conservation and/or neglect of the existing Ottoman built environment.
\end{abstract}

Keywords: Ankara, Tirana, nationalism, urban planning, capital city, Ottoman Empire, old town, comparative study.

\footnotetext{
${ }^{1}$ Dr., Faculty Member, IAED, Kadir Has University, E-mail: denizavcihosanli@gmail.com

${ }^{2}$ Assistant Professor, ARCH, Yeditepe University, E-mail: giusepperesta.arch@gmail.com

idealkent @ C Kent Araştırmaları Dergisi (Journal of Urban Studies) 


\title{
Bir Ulus ve Modern Bir Başkent İnşa Etmek: Ankara ve Tiran'ın İlk İmar Planlarının Karşılaştırmalı Bir İncelemesi
}

\author{
Deniz Avc1 Hosanl ${ }^{3}$ \\ ORCID: 0000-0003-1157-5654
}

\author{
Giuseppe Resta ${ }^{4}$ \\ ORCID: 0000-0001-8489-5291
}

Öz

Bir zamanlar Osmanlı bayrağı altında birleşen iki başkent, Tiran ve Ankara, sırasıyla 1920 ve 1923'te farkl ulusal bayraklar altında yeni başkentler olarak belirlenmişler; ideolojik ve fiziksel olarak benzer bir kentsel gelişim sürecini paylaşmışlardır. Osmanlı İmparatorluğu'nun dağılmasindan sonra her iki şehir de önemli dönüşümlere sahne olmuştur. Kentsel gelişimleri, kentsel elemanları ve yerleşim örüntüleri bakımından güçlü bir yabancı etki/destek altında; Ankara için davet edilen ve hizmetlerinin karşılı̆̆ı ödenen yabancı teknokratlar ve Tiran için yabancı faşist yöneticiler aracılığıyla benzer şekilde gerçekleşmiştir. Bu makale, bu iki şehrin ilk kentsel imar planlarını, yani Carl Christoph Lörcher tarafindan çalışılan Ankara planı ve Gherardo Bosio tarafından çalışılan Tiran planı ve uygulamalarının arkasındaki yaklaşımları değerlendirerek, ideolojik ve fiziksel dönüşümlerinin karşılaştırmalı bir analizini sunmuştur. Çalışma göstermiştir ki, yeni yükselen milliyetçi rejimler, kentsel planlamayı ideolojik modernleşme ve ulus inşası gündemlerini uygulamak için bir araç olarak kullanmışlardır. Metnin odak noktası, iki modernist planın tabula-rasa yaklaşımı ile eski mevcut Osmanlı yapılı çevresinin korunması velya ihmali arasında nasıl salındığın ilişkilendirmek olmuştur.

Anahtar Kelimeler: Ankara, Tiran, milliyetçilik, şehir planlaması, başkent, Osmanlı Imparatorluğu, eski şehir, karşılaştırmalı çalışma.

\footnotetext{
${ }^{3}$ Dr., İç Mimarlık ve Çevre Tasarımı, Kadir Has Üniversitesi, E-mail: denizavcihosanli@gmail.com

${ }^{4}$ Dr. Öğretim Üyesi, Mimarlık, Yeditepe Üniversitesi, E-mail: giusepperesta.arch@gmail.com

idealkent @ C Kent Araştırmaları Dergisi (Journal of Urban Studies)

http://idealkentdergisi.com

Geliş Tarihi Received Date: 23.08.2021 Kabul Tarihi Accepted Date: 26.12.2021
} 


\section{Introduction}

Ankara valley, located in an area called 'Middle Valley' (Orta Yayla) in central Anatolian region, is located at an altitude of 1016 meters above sea level, and the historic Ankara town is located on a 152 meters small hill (Aydın, Emiroğlu, Türkoğlu, \& Özsoy, 2005, p. 21), surrounded by 'three or four small others' (Madran, 2001, p. 156; Poujoulat, 1841) above this valley. It is surrounded by high mountain ranges from north and south thus shielded from winds while also providing water deposits which balance characteristics steppe droughts (Aydın et al., 2005, p. 19). To the east, there is a mountain called Elmadağı (Apple Mountain, $1862 \mathrm{~m}$ ) which provided most of the water resources to the historic city (Şimşir, 2006, p. 37). The historic citadel and the scattered historical Ottoman neighborhoods towards the southern, eastern and western skirts are located between a winding affluent called Hatip Stream (Bentderesi) which cuts through the rocky surfaces to the north and connects with its smaller southeastern northwestern running affluent called İncesu Stream at its western path.

Tirana as a relevant urban center has a recent urban history ${ }^{5}$ (Aliaj, Dhamo, \& Thomai, 2016). It is located on a slightly sloped plain between 100 and 130 meters above sea level, furrowed to the north by the Tirana River and further south by the Ishmi affluent Lana. This position is protected on three sides and shielded from northern winds. The Dajti Mountains $(1600 \mathrm{~m})$ to the North are fundamental geographical and visual reference for the city since its foundation.

Despite these cardinal differences of the new settlements, the urban development of these two formerly Ottoman cities occurred in a congruent fashion including urban components and settlement patterns following the new master plan proposals by the foreign, i.e., European architects under the influence of European town-planning criteria of the early twentieth century concerning the garden-city movement (Benevolo, 1971, pp. 351-358). The concordance of the master plans is not simply because of the geographical similarities but also because of the ideological agenda that swept through the nation-states after the disintegration of the Ottoman Empire.

\footnotetext{
${ }^{5}$ The opposition by other more populous and wealthy cities to elect Tirana as capital is mentioned by Castiglioni (1941). According to Barbarich, at the beginning of the century, the population was only 17.000 (Barbarich, 1905, p. 295).
} 


\section{Aim and Scope}

The aim of this article is thus to understand the urban development in Ankara and Tirana within their socio-political context after the fall of the Ottoman Empire and the rise of new nationalist regimes which assimilate nation-building propaganda by the first urban plans as a tool to implement ideological modernization and nation-building agendas. On one hand, while the first implementation of a modernist urban plan in Ankara has been the outcome of a nationwide debate with external influences, the plan of Tirana was mainly being laid out by foreign architects during a dictatorship. Additionally, there is a decade difference between the first master plans of Ankara and Tirana.

On the other hand, they conveyed similar characteristics that can be listed as: (1) Small Ottoman towns became the new capital cities of new nations, (2) new urban development plans were developed under the influence of the European urban planners, (3) they display a similar topography (high lands of the old city \& low lands of the new city or vice versa), (4) the similar ideological charges behind the new urban growth on north-south axis, (5) both urban development plans clearly separate the 'old' Ottoman parts of the cities from the 'new' modernized settlements, (6) the new urban components (boulevards, squares etc.) are loaded with similar ideological meanings, and perhaps most importantly, (7) the 'unintentional' conservation of the 'old' parts of both cities were achieved by a lack of interest for the historic built environment.

These cities became the capital cities of new nations despite ideological differences in the formation of 'nations.' Uprisings began in Albania after the increase in the nationalist movement in Europe at the beginning of the 1900s and consequently, Albania became free of the Ottoman rule during the Balkan Wars during the 1910s (Hall, 2000). However, among the Muslim-Turkish population of the Ottoman Empire, the concept of 'nation' was unfamiliar; with the nationalism movements in Europe and with great land loss and wars, as a counterpart of 'nationalism', different concepts were discussed such as 'Ottomanism' or 'New Ottomans' (Berkes, 2014, p. 282) or 'Islamization' (Berkes, 2014, p. 271). At the end of the nineteenth century, because of unsuccessful unification of the Ottoman entity under these concepts, a new one was born, which became 'Turkism' (Berkes, 2014, p. 411). After the Independence War, the Turkish Republic was established as the reborn child of the Ottoman Empire. Thus, unlike Albania which was part of conquered lands by the Ottoman entity, the new Republic embraced its Ottoman past, 
and considered itself as the continuation of it. Consequently, it could be argued that the process of 'nationalism' was quite different in the contextual backgrounds of two countries, but the resultant birth of new nations is similar.

'Turkism' found basis during the turmoil at the end of the nineteenth century and continued up to the early years of the Turkish Republic (Aslanoğlu, 2010, p. 30). The 'Young Turks' after the declaration of Constitutionalism in 1908 sought for the regeneration of the empire with a commitment to the Ottoman Empire's ethnical and religious past but with a patriotic approach to the new and modern Turkish nation (Bozdoğan, 2012, pp. 31-33). The 'First National Architectural Style' (Sözen, 1984) provided just the right means for such a transition period, which required a nationalist frame for architecture to represent the newly formed nation-state, giving a sense of historicist identity to the buildings, while also introducing all the modern amenities in building technologies. Ankara became the symbol of the revolutionary character of the period after the establishment of the Turkish Republic as a school for the (re)construction of Anatolia, with the provision of modern urban and daily life to its citizens (Tankut, 2000, p. 301). The Turkish government commissioned the help of 'paid technocrats', i.e., foreign architects and planners to serve their programs.

Tirana, as well as most of the new Balkan capitals, did not share the same continuity in spatial layout and architecture between the pre-national and the national, the pre-modern and the modern, as for the rest of Europe and the other post-Ottoman cities (Therborn, 2017). In February 1920, Tirana became the temporary capital of the new state and was later confirmed on 31 December 1925, but Albania as a whole 'barely re-emerged as an independent state' (Hall, 2000, p. IX). In this context, the growing Italian influence in Albania unfolded in three different stages, ranging from the end of the nineteenth to mid-twentieth century. It started with an investment policy (Iaselli, 2004, 2013; Roselli, 2006) and turned in an autocratic colonization (Aliaj, Dhamo, \& Thomai, 2016; Posca, 2013; Resta, 2016; Resta, 2019).

\section{Modernizing in Urban Scale: Lörcher's Plan for Ankara (1924-25) and Bosio's General Plan for Tirana (1939-1942)}

Ankara as a 'gloomy, dirty, dispersed and neglected town' (Madran, 2001, p. 165; Poujoulat, 1841) - vitalized with railway transportation and enlivened 
trade at the end of the nineteenth century (1892) and devastated once again because of wars - witnessed a massive transformation during the 1920s based on the will to progress and to build a modern nation state (Bozdoğan, 2012). As Ankara became the new capital city, discussions started on the unsanitary urban environment and insufficient urban services (Tankut, 1993, p. 49). With the constantly increasing population and the need of urgent housing, the new capital city required an urban development plan. Thus, only four days after the announcement of Ankara as the new capital city, on 17 October 1923, the Municipality of Ankara was established following the successful Municipality (Şehremaneti) model of İstanbul (Sarığlu, 2001, pp. 43-44). The Municipality of Ankara (Şehremaneti) was officially organized with a regulation number 417 on 16 February 1924 (Aydın et al., 2005, p. 383). During its six-years of service, the new municipality aimed to modernize the new capital city (Tankut, 1993, p. 50) and its most prominent achievement was the initiation of a new urban development plan and the expropriation of new lands for its implementation.

During the same decade, under king Zog I rule, Austro-Hungarian influence was strong in Tirana and led to a plan for the capital whose drawings by the Austrian architect Hans Köhler are dated between 1926 and 1928. ${ }^{6}$ Simultaneously Italy seized larger sector of the Albanian economy overlapping its planning activity with that of the Austrian, until it was time to remove Köhler from his task. Armando Brasini signed the first project for the renovation of the city center (1926). He was an eclectic architect, involved, among other things, as a set designer of the films Theodora and Quo Vadis? One can easily recognize his cinematographic attitude in the row of neo baroque buildings that acted as the spine of his project. The city envisioned by the Roman architect expressed too much extravagance to be seriously considered as a model for a fascist capital. Brasini's solution provided a combination of the classical Italian city with some exotic details, then fenced, in order to be formally and socially self-sufficient.

The idea of self-sufficiency is also the main character of the next plan by Florestano Di Fausto (1929-31), eventually finalized by Gherardo Bosio (193941). Bosio's plan conveyed the first comprehensive vision of Tirana as a whole and unified all previous local attempts (Figures 1\&2). A regulation that has been found in the Central Technical Construction Archive - AQTN (Arkivi

\footnotetext{
${ }^{6}$ Historical documents have been retrieved at the historical archive of the municipality Arkivi Qëndror Teknik i Ndërtimit (AQTN) during the period 2016-2018.
} 
Qendror Teknik i Ndërtimit), the Legge sui municipi in 5 titoli e 214 articoli, defined Albania's new administrative system. It was decided that municipalities should have three decision-making bodies: Kuvendi, Consiglio and Capo. ${ }^{7}$ A staff of 57 employees is assigned to Tirana, including a technical office with two civil engineers, an architect, a surveyor, a draughtsman and two administrative clerks. The $1 \%$ of custom duties on all goods imported in Albania is to be allocated for the plan of Tirana Nuova. ${ }^{8}$ The remaining $10 \%$ will finance nationwide projects. Tirana generally benefits from a quarter of the national revenue. ${ }^{9}$ Legge sui municipi in 5 titoli e 214 articoli overruled the laws on the municipality of İstanbul that were also implemented in Tirana for centuries. ${ }^{10}$

One of the initial initiations of Ankara's Şehrameneti (Municipality established on the model of İstanbul Şehremaneti of the Ottoman era) was the expropriation of the 400 hectares of lands established with regulation 583 dated 24 March 1925 towards the south of the old city (Aydın et al., 2005, pp. 384385; Cengizkan, 2004, p. 47; Tankut, 1993, p. 54). The commission to prepare a new urban development plan was given to a private company called Construction Turkish Incorporated Company (İnşaat Türk Anonim Şirketi) and the company requested the plans from the former member of the Construction Committee of İstanbul (İstanbul İmar Komisyon Üyesi), Dr. Carl Christoph Lörcher (1844-1966), a German architect/planner (Figures 1\&2) (Aydın et al., 2005, p. 390; Cengizkan, 2002; Tankut, 1993, pp. 54-57). Lörcher's master plan was designated for a population of 100,000 to 200,000 (Cengizkan, 2004, p. 47) and with a density of approximately 500 people/ha (Table 1). Lörcher prepared three plans: the old city plan for Ulus in 1924 which was unapproved, the new city plan in 1925 which was approved and a combined old city - new city plan in 1924-25 which was in 1:10,000 scale (Cinar Ozdil et al., 2019, p. 3). The new settlement area was literally called the 'New City' - Yeni Şehir. However only 300 hectares could be expropriated and Lörcher used only 150 hectares of it for the new city (Cengizkan, 2004, p. 49).

Lörcher was a 'garden city' advocator, thus, he proposed a network of public open spaces including wide recreational areas, squares, gardens and greenways, lining the existing watercourses with green walking strips on both sides (Cinar Ozdil et al., 2019, p. 4). Lörcher's 'garden-city' concept

\footnotetext{
${ }^{7}$ Legge sui municipi in 5 titoli e 214 articoli, art. 3, AQTN.

8 Addressed at as 'ornamentation tax.'

${ }^{9}$ Legge sui municipi in 5 titoli e 214 articoli, artt. 77-78, AQTN.

${ }^{10}$ Legge sui municipi in 5 titoli e 214 articoli, art. 211, AQTN.
} 
(Akcan, 2009, pp. 41-42), siedlung housing, concerns on public health and public gathering with wide-open areas for physical activities and large squares, and the concept of zoning (bazaar areas, cemeteries, bank areas, housing zones, etc.) started to change the spatial character of the city and the daily life of Ankara dwellers. Similarly, the existing urban fabric changed in size and spatial relationships with the street in Tirana. New building typologies (villa, palace, hospital, school, ministry, hotel, post office) and new urban spaces (the monumental boulevard, the promenade, the piazza, and the porticato) were introduced with Bosio's plan (Resta, 2019).

Table 1. Numerical data concerning the implementation of Ankara's and Tirana's first master plans. Credits: authors.

\begin{tabular}{|c|c|c|c|}
\hline & & Ankara & Tirana \\
\hline \multirow{6}{*}{ Population } & \multirow{2}{*}{$\begin{array}{l}\text { Population before } \\
\text { the plan }\end{array}$} & 33,070 (1907) & \multirow[b]{2}{*}{35,000 (1937) } \\
\hline & & $\begin{array}{l}\text { ca.20,000-25,000 } \\
(1920) \\
\end{array}$ & \\
\hline & $\begin{array}{l}\text { Estimated } \\
\text { population }\end{array}$ & $\begin{array}{l}\text { Löcher's plan - } \\
\text { 100,000-200,000 } \\
(1924 / 25)\end{array}$ & $\begin{array}{l}\text { Bosio, Lambertini, } \\
\text { Poggi's plan - 130,000 } \\
(1939-43)\end{array}$ \\
\hline & \multirow{3}{*}{$\begin{array}{l}\text { Population } \\
\text { increase }\end{array}$} & $47,727(1926)$ & \multirow{3}{*}{95.000} \\
\hline & & 74,533 (1927) & \\
\hline & & $107,641(1928)$ & \\
\hline \multirow{5}{*}{ Area } & \multirow[b]{2}{*}{$\begin{array}{l}\text { Area of the city } \\
\text { before the plan }\end{array}$} & ca.152 ha (1900) & \multirow[b]{2}{*}{500 ha (1937) } \\
\hline & & $\begin{array}{l}\text { ca.300 ha (before } \\
1924 \text { ) }\end{array}$ & \\
\hline & Density & $\begin{array}{l}500 \text { person/ha ( } 300- \\
400 \mathrm{ha})\end{array}$ & 130 person/ha \\
\hline & \multirow{2}{*}{$\begin{array}{l}\text { Area of } \\
\text { implementation }\end{array}$} & \multirow{2}{*}{$\begin{array}{l}150 \text { ha in the new } \\
\text { city (Yenişehir) }\end{array}$} & urban area 1,100 ha \\
\hline & & & $\begin{array}{l}\text { extra-urban area } 1,700 \\
\text { ha }\end{array}$ \\
\hline \multirow[t]{2}{*}{ Period } & $\begin{array}{l}\text { Estimated } \\
\text { implementation } \\
\text { period of the plan }\end{array}$ & 50 years & 60 years \\
\hline & $\begin{array}{l}\text { Implementation } \\
\text { period }\end{array}$ & 1924-1930 & $1939-43$ \\
\hline
\end{tabular}

In Ankara, Yenişehir became the representation of the new face of the new Turkish Republic and demonstrated the will to build a new nation-state with its clean, sanitary and organized environment as a triumph of modernization. 
The old and new cities were connected by a preeminent monumental boulevard running north to south (Figures 1\&2, Figure 3, n.1), an ideological axis, connecting the rich historical culture of historic Ankara to contemporary development and progress. Lörcher called this the Nation (Millet) Street [Strasse der Nation] (Cengizkan, 2004, p. 89) which later became the Gazi Mustafa Kemal Boulevard. Even though these two parts of the city were connected, they were also physically divided from each other from west to east with the railways cutting this axis perpendicularly and acting as a boundary, further consolidating this physical segregation between the old and the new cities.

The idea of a large monumental axis is also the main feature of Bosio's plan (Figures 1\&2, Figure 3, n.1). The two-kilometer long boulevard, aligned in the north-south direction, conformed the spatial structure of the whole project to a hierarchical grid system. Skanderbeg Square became the connection point of the old city with the Tirana Nuova (Figure 5a). Such boulevard, Viale dell'Impero, was designed as a scene to represent the power of the regime. Indeed, monumental buildings had very large façades against a limited floor area, with a 10-12m wide cross section. Already in Di Fausto's project, it was clear that 'the new large boulevard should end towards the hills covered with olive trees, with a complex of royal buildings raised along the hillside'.$^{11}$

\footnotetext{
${ }^{11}$ F. Di Fausto, Tirana, pro-memoria per l'ufficio d'Albania, 1936, MEST. Though the monumental boulevard is generally credited to Di Fausto, an early schematic version can be found in the 1926 Plan $i$ Tiranës së Ré by Köhler as noted by Yarwood (2011).
} 


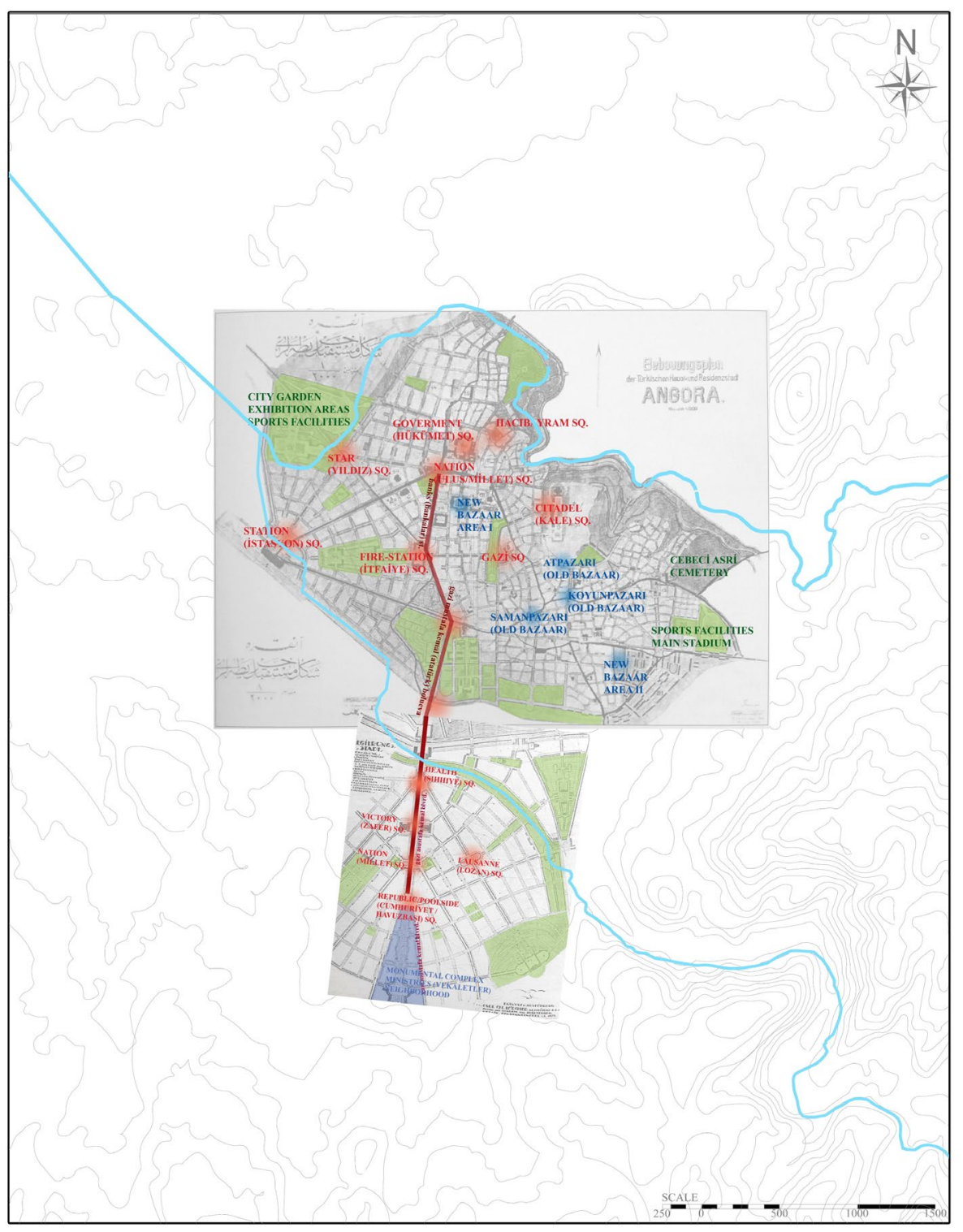

Figure 1a. The Old and New City Urban Development Proposals of Lörcher in 1924-25. (Base Map Source: METU, 1924-25; Cengizkan, 2004). All markings are added by authors. 


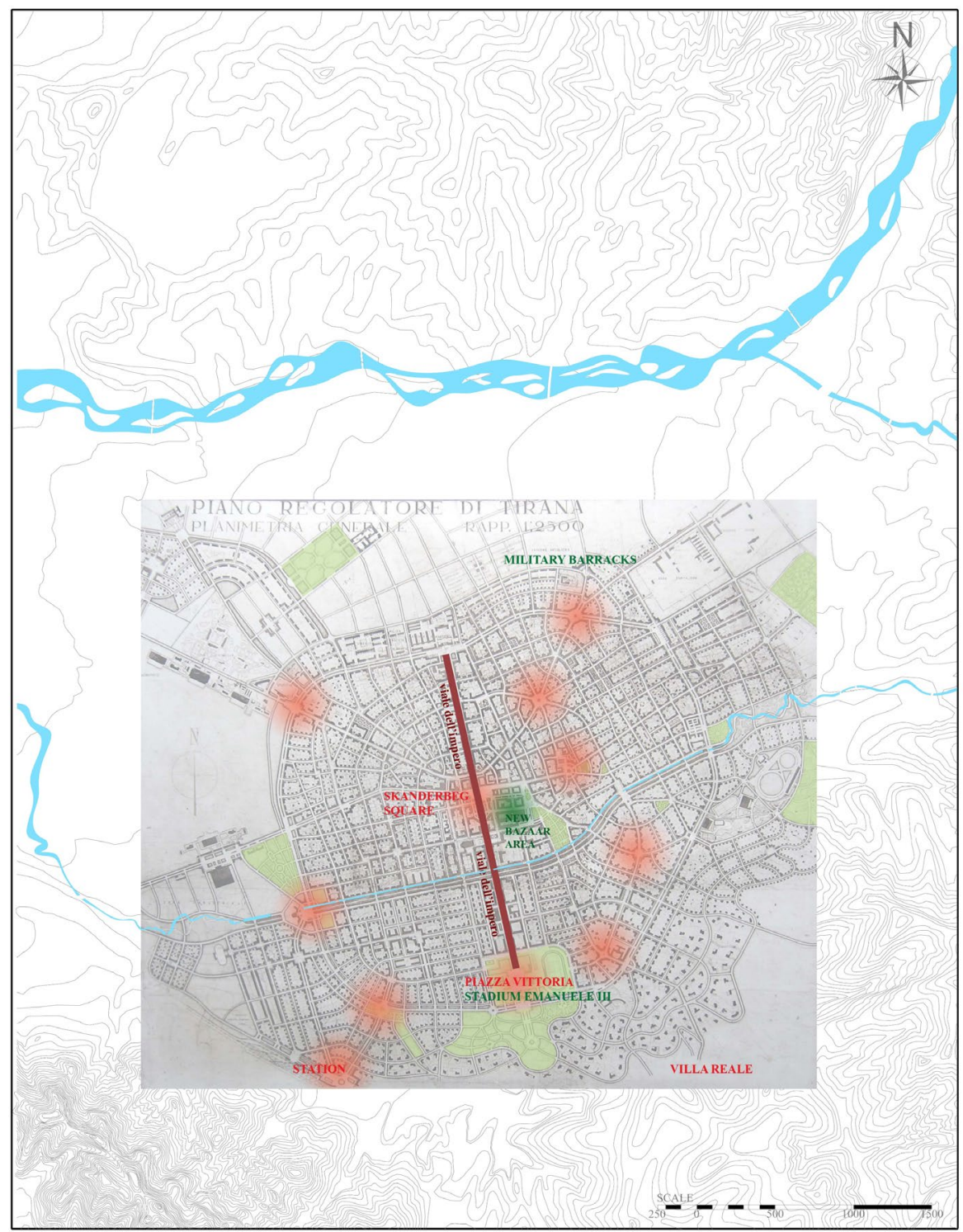

Figure 1b. General plan of the Piano Regolatore di Tirana by Gherardo Bosio elaborated in 1939-41. (Base Map Source: AQTN, 1939-41). All markings are added by authors.

At the end of the boulevards in both cities, monumental complexes were proposed (Figure 3, n.2). In Ankara, the Gazi Mustafa Kemal Boulevard led to an enormous triangular block, proposed as the new Ministries Neighborhood (Vekaletler/Bakanliklar) (Figure 5c \& 5d). In Bosio's plan, at one end of the 
boulevard was the administrative district gathering all the ministry buildings, while at the other end was the epicenter to celebrate the fascist spirit including a city garden, entertainment facilities and a stadium (Figure 3, n.3 \& n.4, Figure 5c \& 5d). In Ankara, the entertainment facilities and the city garden were separated from the Ministries Neighborhood and was placed at the northwestern border of the old city (Figure 3, n.3 \& n.4). The preeminent stadium was further separated from these and it was proposed at the eastern border of the old city among the newly proposed housing zones (Figures $1 \& 2)$. In Tirana, the complex holding the stadium, the Gioventù del Littorio Albanese (Albanian Littorio Youth Centre), the Opera Dopolavoro Albanese (Albanian National Recreational Club) and the Casa del Fascio, the centerpiece of fascist planning, was the ending point of the monumental boulevard (Figure 5b). ${ }^{12}$ Italians wanted to replicate their western lifestyle in contrast with the Ottoman built environment on the opposite side of Skanderbeg Square. However, despite all attempts to erase the Ottoman image, on one of the sides of this monumental square, a bazaar was proposed resembling the han-bazaars of the Ottoman towns (Figures 1\&2, Figure 3, n.5). While in Ankara, several historic bazaar areas including the historic hans were still in use and Lörcher himself proposed the Tahtakale Bazaar as the main bazaar area (main bazaar area I) close to the commercial heart of the old city (Figure 3, n.5, Figures 1\&2). This bazaar was close to one of the main squares in the old city: the new Nation Square marking the end of the monumental boulevard at the skirts of the historic citadel (Figure 5a).

12 UCEUA, Report of the Tirana General Plan, Piano regolatore del centro di Tirana, 1940, AQTN. 


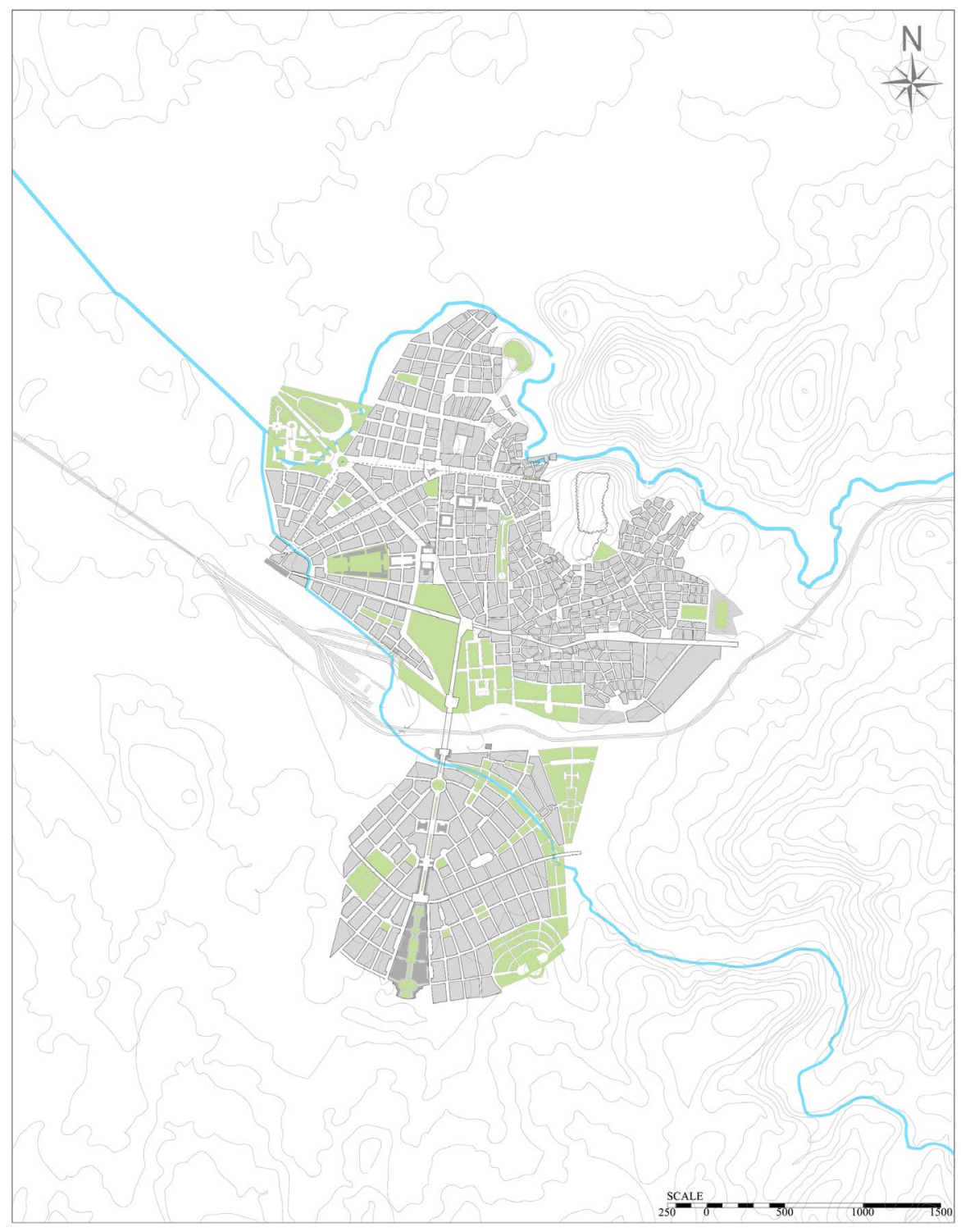

Figure 2a. First Urban Development Plans: Lörcher's Master Plan for Ankara (1924-25). Credits: authors. (Base Map Source: Goethe Institut, 2021). 


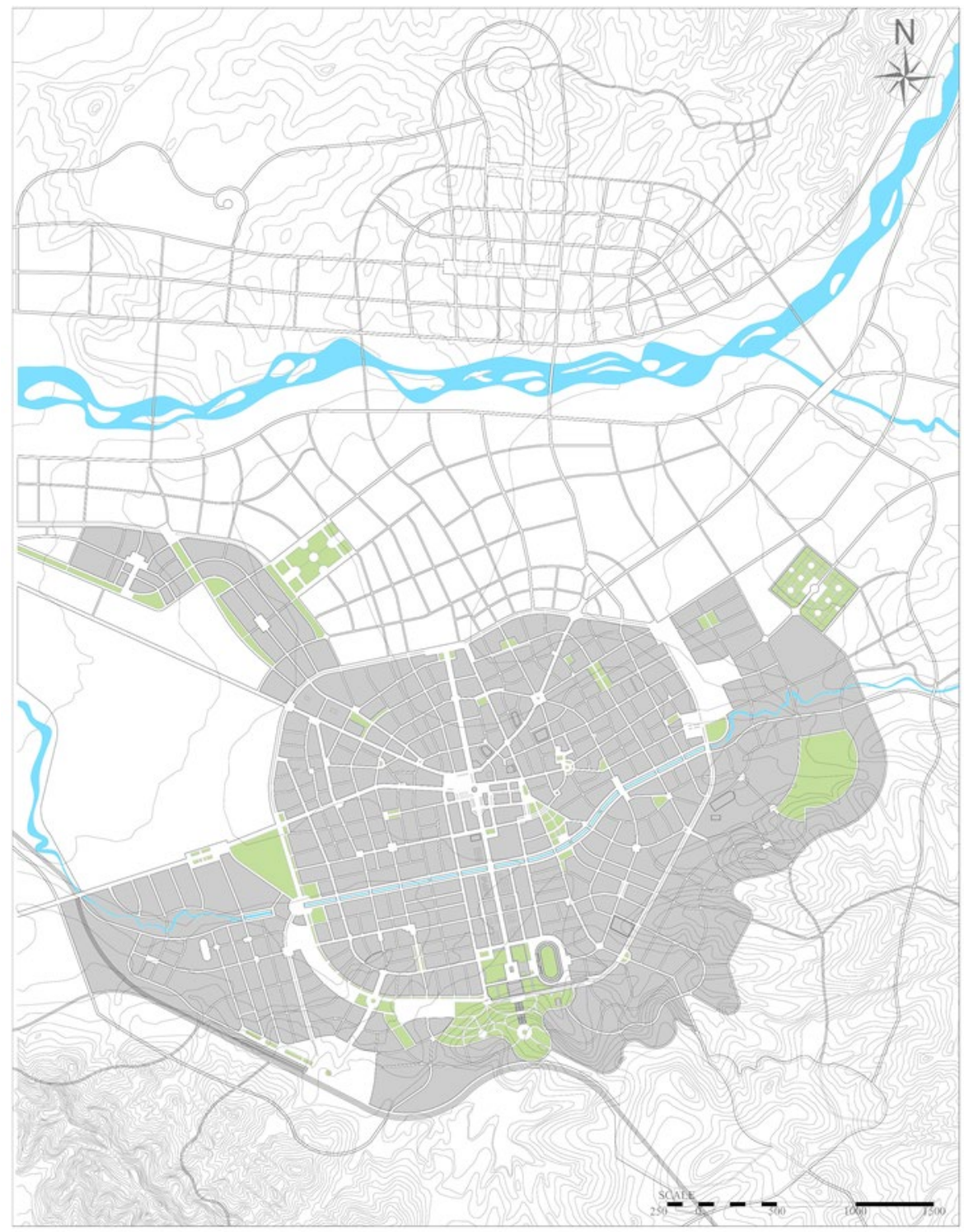

Figure 2b. First Urban Development Plans: Bosio's Master Plan for Tirana completed by Poggi and Lambertini (1939-43). Credits: authors. (Base Map Source: AQTN, 1939-43).

In Ankara's new master plan, rather than one monumental square like in Tirana, there were sets of squares proposed along the principal monumental boulevard (Figures 1\&2, Figure 3, n.6). Several were scattered in the old city such as Station (Istasyon), Nation (Ulus/Millet) (Figure 5a) and Fire-Station 
(Itfaiye) Squares, the latter on the old city side of the monumental boulevard. Nonetheless, in the new city, similar to the Skanderberg Square in Tirana, the visual and physical transition occurred from the organic settlement of the Ottoman built environment to the new city with the planned geometry of the Sanitary-Health (Sihhrye) Square, which acted as a gate to the organized and healthy contemporary city after the clearly marked boundary of the railways. Two other squares followed on the urban axis: the Victory (Zafer) Square and another Nation Square (Figures 1\&2). In the former, a victory monument was placed designed by an Italian sculptor Pietro Canonica in 1927 (Figure 5b). It was the sculpture of Atatürk, designed to face the new city with his back to the old, stood as an ideological symbolic message for 'looking to the hopeful future' (Çolak, 2012, p. 857; Moricz, 1930, pp. 37-39). The most prominent conceptual and ideological square of the new city, following the first three, was the Republican (Cumhuriyet) Square, later known as the Fountain/PoolSide (Havuzbaşı) Square due to its later added sculptured-fountain called 'Water Fairies' (Su Perileri) (Figure 5c) (Türkyılmaz, 2015, pp. 124-125). This square became the intersection point connecting all parts of the city (old city from the north, ministries neighborhood from the south, the Gazi farm complex from the west and the Liberation [Kurtuluş] Park from the east) as the western-eastern axis cut the monumental northern-southern one and formed a cruciform at the heart of the new city. Lörcher further proposed several axes which connected the landmarks with the Nation Square and the historic citadel in the old city for vehicular and pedestrian traffic, whereas the old and the new parts of Tirana were surrounded by a series of ring roads that connected all peripheral suburbs with the main axis, Viale dell'Impero (Figure 3, n.7, Figure 5a). 

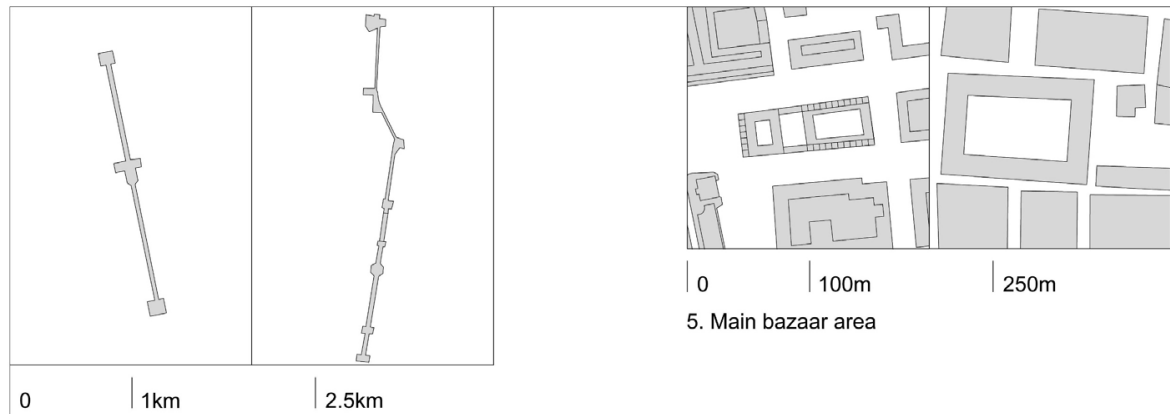

1.Monumental boulevard

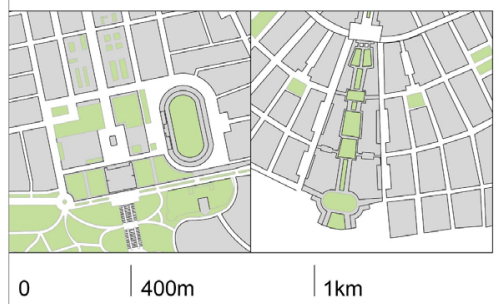

2. Monumental complex

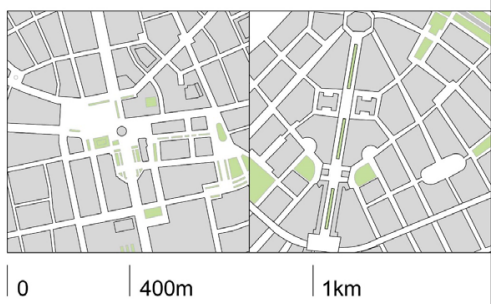

6. Main square / Sets of Squares

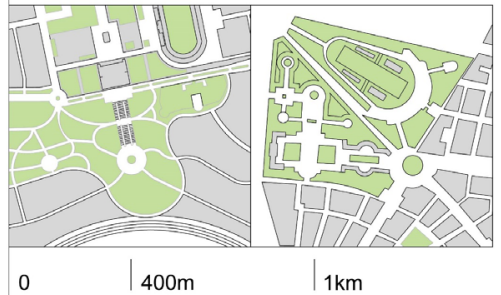

3. Main city park

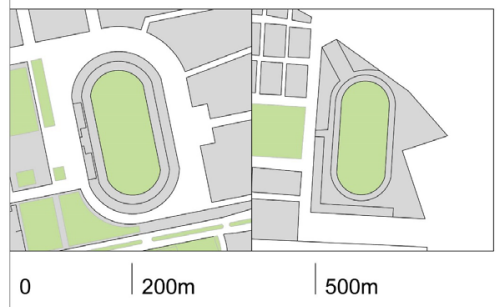

4. Stadium

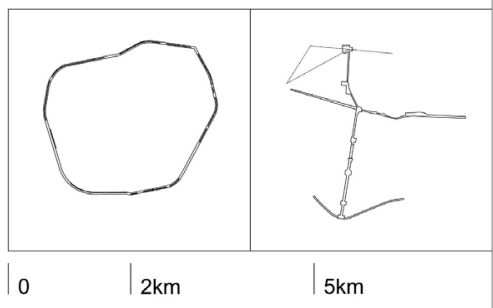

7. Vehicular Traffic

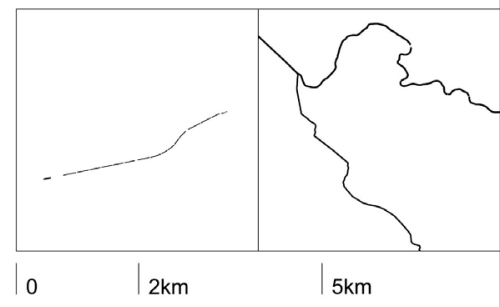

8. Urban river

Figure 3. Comparison of urban elements in Bosio's and Lörcher's master plans. Credits: authors. Per each item on Left: Tirana, on Right: Ankara. 
The construction of a large residential neighborhood completed the surroundings of the urban axis in Tirana. Every part of the boulevard was controlled from a street-level vantage point. In the urban regulation of Viale dell'Impero, Bosio set a $42 \mathrm{~m}$ wide carriageway flanked by a continuous and uniform front façade-line. Every elevation had to be conformed to a spatial module of $4 \mathrm{~m}$, affecting then also the rhythm of the fenestration and the structural span. Being on a flatland, heights of the floors were required to be recurrent: four floors above the ground, with the cornices set at $17 \mathrm{~m}$, and the first floor at $6 \mathrm{~m}$ regardless of the functional program (Art. 6). In almost all edifices, the subdivision of the classical palazzo, base - piano nobile - top, marked the façade. The base (basamento) as well as all architectural decorations should be made in marble or stone (Art.9). ${ }^{13}$ Restrictions were provided for setbacks, plantations, distances, coverage area and even instructions to avoid any blind elevations that could be visible from the street. Very little space was left for local variations as proof that such urban plan was instead a totalizing new vision of the built environment. Though Bosio's Tirana Nuova was not physically enclosed within a fenced area, it was formally, socially and visually separated from the existing urban fabric (Posca, 2013; Resta, 2019).

Yenişehir was imagined as the new housing zone fit for the new nation, hygienic and airy, built of stone and concrete - as a perfect image of the modernist manifesto - and many single-family houses were built along the monumental boulevard (Figure $5 \mathrm{~b} \& 5 \mathrm{c}$ ). These houses were placed in wide gardens and courtyards, surrounded by parks and greenery following the garden-city concept. European/western in urban planning, infrastructure and even with 'modernized' interior spatial transformation but traditional/historicist in formal appearance, and as if designed with controlled regulations, these houses were uniform in execution, following the historicist style of the period, i.e., the First National Architectural Style, giving them an exotique and oriental character (Karaosmanoğlu, 2015, pp. 127-128) (Figure 5c).

Streams were esteemed as urban elements in both plans (Figure 3, n.8). In Bosio's master plan for Tirana, the conservation of the affluent as the urban river was the result of deliberate planning. However, even though Lörcher disregarded the northern Hatip Stream in his master plan for Ankara, by neither deliberately removing nor specifically conserving it, he proposed the Incesu Stream as part of the eastern section of the new city and proposed

${ }^{13}$ UCEUA, Regulation of the Tirana General Plan, Piano regolatore del centro di Tirana, 1940, AQTN. 
greenery areas surrounding it and left it in it course around the old city's southeastern borders at the station quarter (Figure 3, n.8).

Ferdinando Poggi and Ivo Lambertini finalized the Tirana General Plan with a Regional Plan in 1942-1943. This project detailed future directions of expansion of the metropolitan area across the Tirana River, connected visually and physically the city with Dajti Mountains, envisaged interventions in the Old City that needed to be 'sanitized.' ${ }^{14}$ The overall plan foresaw a capital with 130.000 inhabitants, to be completed in 60 years, in an area of $1.100 \mathrm{ha}$ on the model of a garden city. While at that moment, Tirana had a population of 35.000 in an area of 500 ha (Aliaj, Keida, \& Myftiu, 2003, p. 43). After a few months, Germany occupied Tirana and the entire Italian administrative system collapsed.

German occupation occurred only in the field of urban planning and architecture in Ankara, as the new government had invited many German-Austrian architects and planners to the new capital city. At the end of the 1920s, the urgent need for housing and the speculation of the old houses in Ulus and the empty lands in Yenişehir resulted in unplanned constructions and development despite the plans. This 'unplanned' development led to the search for a new plan and the Ankara Municipality organized a competition in 1928. During the competition, the Ankara City Construction Directorate (Ankara Şehri Imar Müdürlü̈̆̈̈) was established with a regulation numbered 1351 dated 28 May 1928 (Tankut, 1993, p. 72). With the selection criteria established by the Ankara City Construction Directorate, the project of Hermann Jansen (1869-1945), another German architect, was selected, announcing a new era of modernization in Ankara with the arrival of many advocates of the German-Austrian Modernism during the 1930s. Many of Lörcher's ideas found reflection in Jansen's master plan which was prepared for a population of 271,000 in an area of 2000 ha, density of 150 person/ha (Tankut, 1993, p. 80).

\footnotetext{
${ }^{14}$ UCEUA, Report of the Tirana General Plan, Piano regolatore del centro di Tirana, Relazione, 1943, AQTN.
} 


\section{Modernist plan and its relation with the Ottoman city: Un-intentional (?) conservation of Ankara's Ottoman city \& Tirana's Italian planning over an Ottoman city}

Ankara's urban pattern as an Ottoman city (Cansever, 2013; Kuban, 2016) before the 1920s was formed of a citadel on top of a hill with historic neighborhoods scattered to the surrounding valleys (Figure 4a). After the arrival of the railways, trade enlivened from 1895 to 1902, however, despite the enlivenment, at some neighborhoods, the traditional residential neighborhoods preserved their devastated seventeenth century appearance. The character of the residential settlements was defined by traditional mud brick masonry houses and/or timber houses scattered around the religious landmarks, lined along the corrugated streets which often ended in cul-de-sac. Neighborhoods where the Muslim and non-Muslim population lived together (such as Hisarönü Neighborhood with Greek [Rum] and Armenian houses, and Jewish Neighborhood) were physically in better condition as their dwellers mostly lived by trade (Şahin Güçhan, 2001). The traditional residential architecture of Ankara followed the Anatolian typology and were planned with a central sofa (loggia) organization. The fires areas, the former non-Muslim neighborhoods, after the 1881 and 1916 fires (Esin \& Etöz, 2015, pp. 76-78), became the new commercial and settlement areas during the 1920s (Avc1 Hosanl \& A Altan, 2018; Avc1 Hosanl1, 2020).

The profile of pre-1920s Tirana displayed sacred spaces marked by cypress enclosures from afar, lines of plane trees shading the banks of the Lana River. After the Italian intervention, skyline of the capital changed, but it was not as dramatic as in other colonies since UCEUA preferred long horizontal perspectives to verticality. Travelers who visited the capital before the Italian occupation experienced an extensive aristocratic city in line with Turkish canons (Degrand, 1901; Roth, 2014). Houses were dispersed according to family groups, each having a walled exterior space, usually a tree lined garden, separated from the street. There were no signs of modern European adaptations, and the buildings were mainly made of mud bricks. Winding streets culminated with a cul-de-sac, all flanked by houses with a rectangular plan of two levels with a central loggia, reminiscent of the Turkish sofa (Figure $4 \mathrm{~b}$ ). As Capolino pointed out, 'the layout could not be compared with the model of the European nineteenth-century city, but it was definitely more than a mere village, as some European visitors described it' (Capolino, 2011, p. 594). Dur- 
ing the Ottoman rule, the old city adapted initially to the lowest alluvial terrace of the area (Castiglioni, 1941), giving Tirana that elongated shape that later morphed in a radial configuration with Skanderbeg Square at the center. In the premises of the 1942-43 town plan, a radical replacement of the old city was expected, performed in the name of urban hygiene and adjusted on the canons of the modernist propaganda (Resta, 2016).

Lörcher's old city plan for Ankara required major investment on the renovation of the historical/traditional fabric and thus it was rejected by the municipality because the new settlement areas within the existing city limits were few and problematic for new constructions (Figure 4a). These problems included steep topographical layout, property problems, accumulation of costs to renovate the infrastructure. It was mostly about the lack of sources for investment: The war-worn new government only wanted to invest in the construction of a new city and the concurrent protection of the traditional fabric was 'beneficial'.

Unlike in Ankara, the general approach toward the old city was quite decisive in Tirana. In the report of the final town plan, signed by Lambertini and Poggi in January 1943, it is noted that Tirana 'has no environmental characters of great value to be defended or preserved, except for the Old Mosque and the Ethem Bey Mosque. ${ }^{\prime 15}$ Other mosques have a 'picturesque value, giving a peculiar tone to the environment.' ${ }^{16}$ On the other hand, the bazaar 'was so heavily transformed in recent years [...] that it now was just a disordered set of shops, warehouses and houses that are unhealthy and precarious.' ${ }^{17}$ The so-called 'Turkish city' 18 was meant to be gradually transformed and replaced with modern houses and villas.

\footnotetext{
${ }_{15}$ UCEUA, Report of the Tirana General Plan, Piano regolatore del centro di Tirana, Relazione, 1943, AQTN, 7. The 'environmental' adaptation of the Italian colonial planning was discussed by Carlo Emilio Rava on the pages of Domus and Rassegna Italiana (Rava, 1928, 1931, 1941).

16 UCEUA, Report of the Tirana General Plan, Piano regolatore del centro di Tirana, Relazione, 1943, AQTN,7.

${ }^{17}$ Ibid.

${ }^{18}$ Castiglioni, Bosio, and Lambertini used interchangeably the word 'Turkish', 'Ottoman', and 'indigenous' to address the old town in all reports.
} 


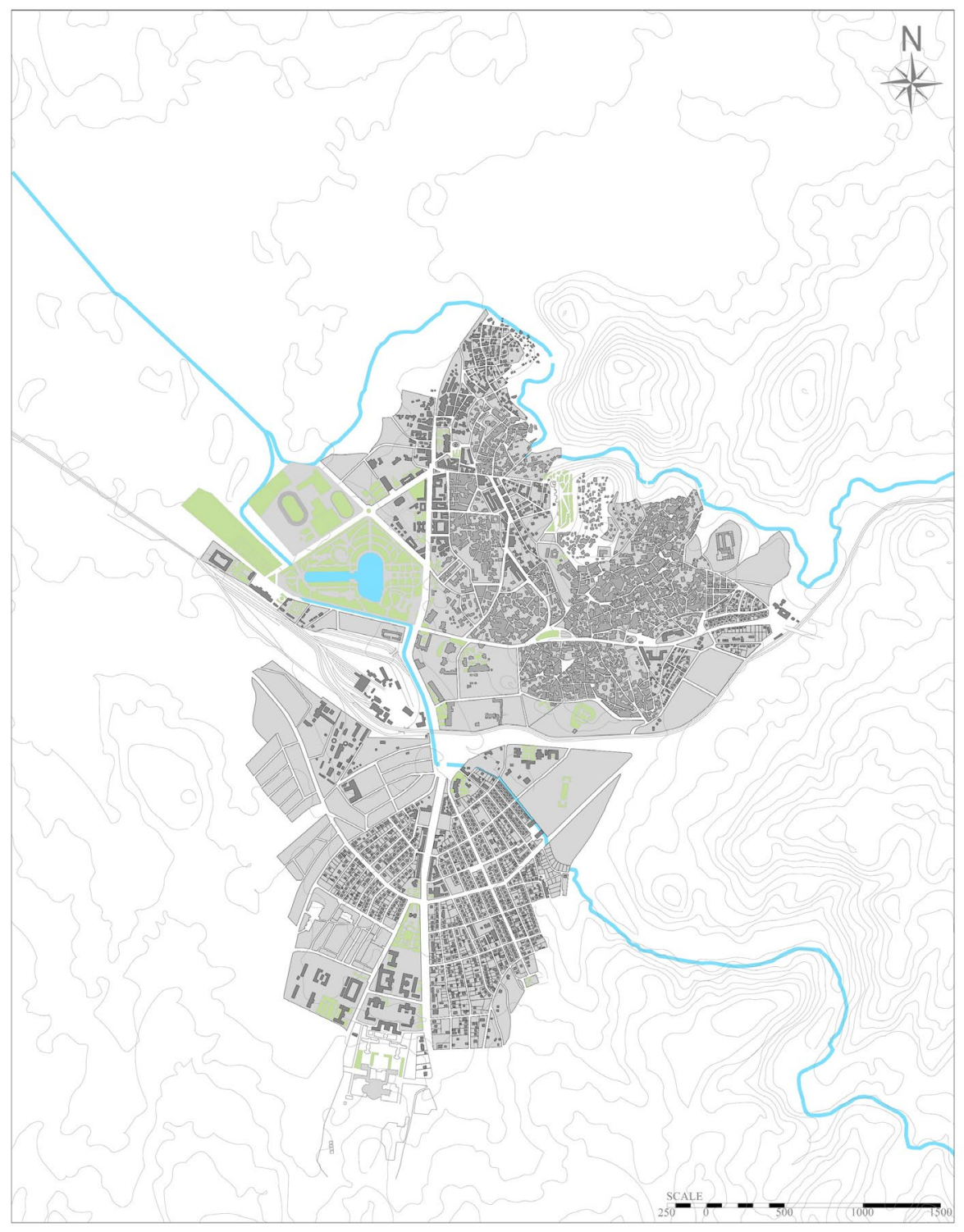

Figure 4a. Implementation of Master Plans (1930s-1940s): Ankara. Credits: authors. (Base Map Source: İnönü Encyclopedia, 1948). 


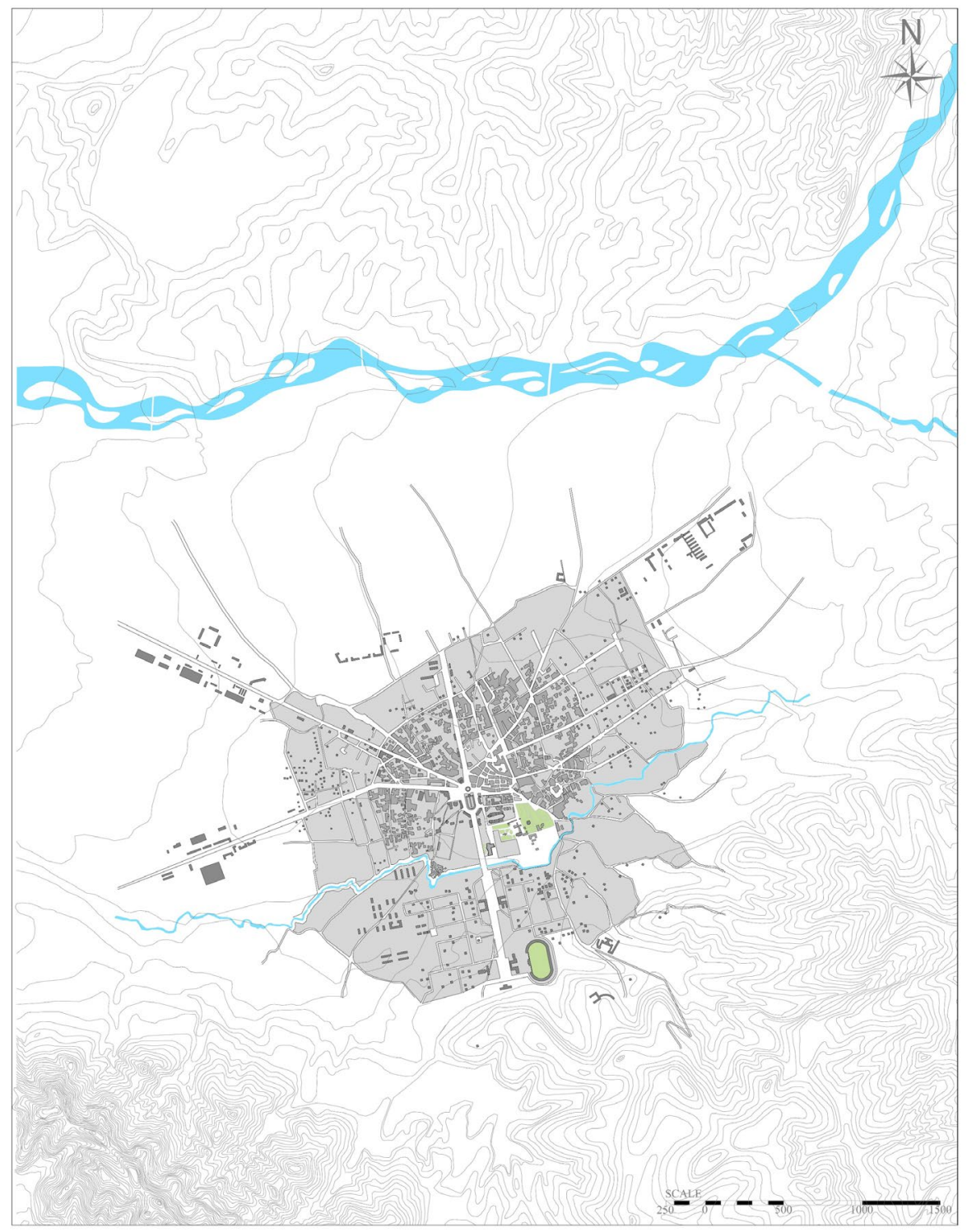

Figure 4b. Implementation of Master Plans (1930s-1940s): Tirana. Credits: authors. (Base Map Source: AQTN, 1949). 


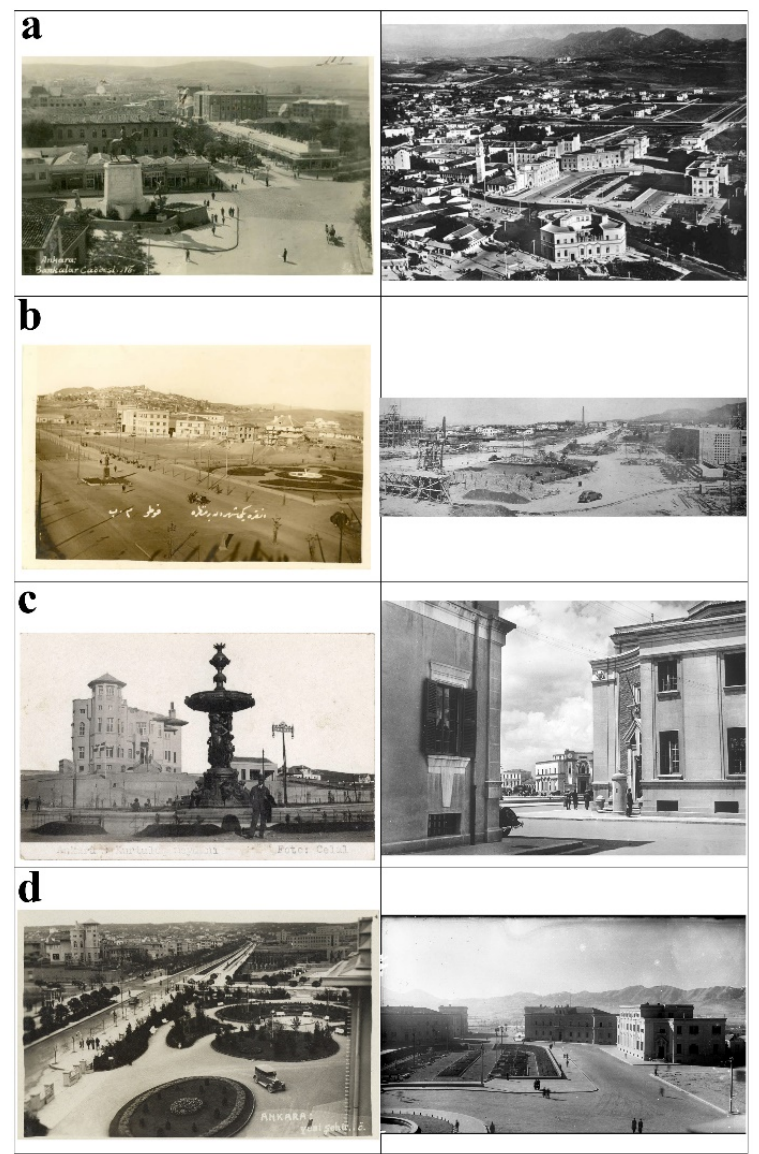

Figure 5. (a) Ankara, Nation Square, Old City (Ulus) (Source: VEKAM, 1930); Tirana, aerial view of Skanderbeg square and the Viale Imperiale (Source: Distaptur, 1940-42). (b) Ankara, Victory Square, New City (Yenişehir) (Source: VEKAM, 1927-28); Tirana, Vittorio Emanuele III square and Casa del Fascio under construction during the 1930s (Source: A Italia no mundo, 1940). (c) Ankara, Republic Square, New City (Yenişehir) (Source: SALT Research, 1930); Tirana, ministry buildings designed by Florestano di Fausto and Skanderbeg Square, detail of the facade. (Source: Fondo Francesco e Franco Tagliarini, 1920-

30). (d) Ankara, Gazi Mustafa Kemal Boulevard, Republic Square and the Ministries Neighborhood, New City (Yenişehir) (Source: SALT Research, 1930-40); Tirana, Skanderbeg Square (Source: Distaptur, 1930).

Even though the Ankara Municipality rejected Lörcher's development plan for the old city (Tankut, 1993, p. 54) with the housing insufficiency argument and impetuosity to construct in the empty lands, the old city, Ulus, developed nonetheless with the initial decisions of Lörcher. Despite the general 
indecisiveness of the old city plan, some ideas were quite precise. Like in Yenişehir, the vehicular and pedestrian paths were paved and trees were planted on sides; all to establish a contemporary and prestigious image suitable for the capital city. For example, Station Street, already existent after 1892, continued to be one of the distinctive axes and it was paved, maintained and planted with trees as a first attempt to build a prestige boulevard in the capital city. Banks (Bankalar) Street, another prestige street with the banks' central directorates, public institutions' office buildings and hotels became the face of the new social life and later the first part of the monumental axis of the new Ankara. The distance between two parts also provided suitable atmosphere for 'neglecting' the old city since the new one, Yenişehir, was planned at an ideal distance, displaying an image of health, hygiene and sanitation: a brand new city to be displayed and admired (Figures 1, 3, 5b and 5d).

At the end of the 1930s, UCEUA confronted an Ottoman-based urban fabric in Tirana, clustered around mosques and bazaars. Around the core of the town were fortified building typologies dominating a pseudo-feudal territorial organization system, which was typical in western lands of the Ottoman Empire (Hirst, 2005). The result was a number of nuclei that later welded in an irregular fabric (Aliaj et al., 2003). Such fragmentation was an easy target for Italian planners that redesigned the existing situation with what they used to call sventramenti (disembowelments) to let new axes and piazze cut through the old city (Figures 1b, 2b and 3). Joseph Roth's 1927 account of Tirana, written for the Frankfurter Zeitung, described the capital as a body waiting for a surgical operation: 'bazaars have been knocked through, houses split and scalped, in order to make Tirana an up-to-date capital city. The half-buildings stand there, with black guts open' (Roth, 2015).

Today is important to bear in mind that the blending of western and eastern characters in contemporary Tirana is not the result of a visionary modernist plan, which intended to respect and enhance the old city. It is rather the product of historical circumstances that did not allow the completion of the 60-year plan laid out by Lambertini and Poggi. The end of the Second World War pushed back Italian influence on Albania and arrested the UCEUA activity. While Bosio's first intention was to 'not lose the vestiges of the Muslim city' (Cresti, 1996, p. 77), also for resource-wise reasons, the long-term vision for the capital suggested by the 1943 plan was that of a modernization by superimposition (Figure 4b).

Furthermore, urban interventions within the consolidated old city required a custom funding mechanism to speed up transformations. In case of 
openings of new roads, extension or rectification of existing ones, landowners affected by such modifications would pay a property appreciation tax equal to $2 \%$ of their value gain. As for private development, a construction tax was assessed at $1.5 \%$ of the overall construction costs. ${ }^{19}$ Hence, the whole process stood on appreciation parameters, while old city was described as an exotic environment with an oriental pattern. Recurrent use of words such as 'picturesque', 'exotic' and 'oriental', in official documents, better explains the simplistic approach toward the existing situation.

Ironically, during the 1920s in Ankara, the new city, and not solely the historic old one, remained 'exotic', 'picturesque' and 'oriental' in appearance despite all the modernization attempts due to the historicist national architectural style of the period (Figure 5c). This was to be harshly criticized by the same actors of the built environment with the arrival of the 1930s.

\section{Conclusions}

Several Italian and Albanian commentators praised the Italian town planning activity, especially Bosio's, and the Turkish authorities ordained the development of the hygienic new city apart from the old in Lörcher's plans to demonstrate the solicitous modernization of the new state. In this study, it is argued that such judgment should be contextualized.

The plan for Tirana served as a reference for the later zoning of the city; its urban structure, though not immediately executed, was the base for infrastructure and future development after the Second World War (Miho, 2003). Tirana in that moment was a capital with no infrastructure at all and the work carried out by SVEA was crucial for basic national communication. Meanwhile, in Ankara, Lörcher's plan formed the basis for the future development plans, especially of Jansen's with the zoning and the formation of dispersed greenery areas, recreational areas, low-density housing and especially the installation of infrastructure.

On the other hand, in Tirana, the colonial agenda was based on the establishment of a new ideological structure, in which very little space was left for domestic contribution at all scale. Similarly in Ankara, the national agenda focused on the new development rather than improving the historic settlement which was occupied by the dedicated Ankara dwellers to the Independ-

${ }^{19}$ Legge sui municipi in 5 titoli e 214 articoli, art. 125. 
ence War; rather, the new city was given the utmost care occupied by the national-foreigners (Şenol Cantek, 2011), the intelligentsia, and mostly İstanbulian. In both cities, the distance between the historic city center and the new city, caused neglect resulting in unplanned alterations in the former and "unchecked speculative constructions" in the latter (Kezer, 2015, p. 33).

The scope of nationalism is to establish or replace a national identity (Resta \& Gatip, 2021), with the aim to distinguish 'us' from 'the others' recovering fabricated of factual roots (Therborn, 2017). Tirana's plan acted as a laboratory experiment to form the architectural language of a nation soon to be defeated in the war, but ironically on the drawing table until the last day of occupation. Whereas in Ankara, the new capital city was implemented on grounds which "acted" as tabula-rasa and with the implementation of Lörcher's plan, the new Ankara became the trial ground for urban development in Anatolia and an educational field for the rest of the country to spread the modernization agenda via urban planning and architecture. This approach was to be radicalized even further by welcoming many foreign experts to westernize the country during the 1930s, ironically as well, within the nation-building ideologies.

\section{References}

Akcan, E. (2009). Çeviride modern olan, şehir ve konutta Türk-Alman ilişkileri. İstanbul: Yap1 Kredi Yayınları.

Aliaj, B., Dhamo, S., \& Thomai, G. (2016). Tirana, qyteti i munguar. Tirana: Polis Press.

Aliaj, B., Keida, L., \& Myftiu, G. (2003). Tirana, the challenge of urban development. Tirana: Cetis.

A Italia no mundo. (1940). Vittorio Emanuele III square and Casa del Fascio. [Photograph]. A Italia no mundo, December 1940.

AQTN. (1939-41). Piano Regolatore di Tirana by Gherardo Bosio 1939-41. [Map] Arkivi Qendror Teknik i Ndërtimit.

AQTN. (1939-43). Bosio's master plan completed by Poggi and Lambertini. [Map] Arkivi Qendror Teknik i Ndërtimit.

AQTN (1949). "Stato attuale" map in the general plan of the Piano Regolatore di Tirana. [Map] Arkivi Qendror Teknik i Ndërtimit.

Aslanoğlu, İ. (2010). Erken cumhuriyet dönemi mimarllğı (1923-1938). İstanbul: Bilge Kültür Sanat.

Ava Hosanll, D., \& Altan, T. E. (2018). The residential architecture of Ankara during the 1920s: The housing types in the settlement zones of the new capital city. VEKAM Journal of Ankara Studies, 6(2), 183-210. DOI: 10.5505/jas.2018.08108. 
Avc Hosanlı, D. (2020). 1920'lerin Ankara'sindan bir mahallenin ve konutlarınin anlattkları. İdealkent - Journal of Urban Studies, 11(31), 1517-1548. DOI: 10.31198/idealkent.795488

Aydın, S., Emiroğlu, K., Türkoğlu, Ö., \& Özsoy, E. D. (2005). Küçük Asya'nın bin yüzü: Ankara. Ankara: Dost Kitabevi Yayınları.

Barbarich, E. (1905). Albania. Monografia antropogeografica. Roma: Enrico Voghera.

Benevolo, L. (1971). History of modern architecture. Cambridge, Massachusetts: M.I.T. Press.

Berkes, N. (2014). Türkiye'de çă̆daşlaşma. İstanbul: Yapı Kredi Yayınları.

Bozdoğan, S. (2012). Modernizm ve ulusun inşasl: Erken Cumhuriyet Türkiyesi'nde mimari kültür (T. Birkan, Trans.). İstanbul: Metis Yayınları.

Cansever, T. (2013). Osmanlı şehri. İstanbul: Timaş Yayınları.

Capolino, P. (2011). Tirana: a capital city transformed by the Italians. Planning

Perspectives, 26(4), 591-615. Doi:

https://www.tandfonline.com/action/showCitFormats?doi=10.1080/02665433.20 11.601610

Castiglioni, B. (1941). Appunti sulla capitale dell'Albania all'alba del nuovo regime. Bollettino della Società Geografica Italiana, 6(7), 9-27.

Cengizkan, A. (2002). Ankara 1024-25 Lörcher planı: Bir başkenti tasarlamak ve sonrası. In A. Cengizkan (Ed.), Modernin saati (pp.37-60). Ankara \& İstanbul: Mimarlar Derneği, Boyut Yayın Grubu.

Cengizkan, A. (2004). Ankara'nın ilk planı: 1924-25 Lörcher planı. Ankara: Ankara Enstitüsü Vakfi.

Cinar Ozdil, N., Vejre, H., \& Bilsel, F. C. (2019). Emergence and evolution of the urban public open spaces of Ankara within the urban development history: 1923 to present. Journal of Planning History, 1(19), 26-51.

https://doi.org/10.1177/1538513219848434

Çolak, M. (2012). Macarların gözü ile yeni başkent Ankara (1923-1938). In Y. Kurt (Ed.), Tarihte Ankara uluslararası sempozyumu bildirileri (pp. 847-870). Ankara: AÜDTC Fakültesi Yayınları.

Cresti, C. (Ed.) (1996). Gherardo Bosio, architetto fiorentino. 1903-1941. Firenze: Angelo Pontecorboli Editore.

Degrand, A. (1901). Souvenirs de la Haute-Albanie. Paris: H. Welter.

Distaptur. (1930). Skanderberg square. [Photograph] Distaptur - L'Ente Editoriale di Tirana negli anni 1939-1943.

Distaptur. (1940-42). Skanderberg square and the Viale Imperiale. [Photograph] Distaptur L'Ente editoriale di Tirana negli anni 1939-1943.

Esin, T., \& Etöz, Z. (2015). 1916 Ankara yangını: Felaketin mantığı. İstanbul: İletişim.

Fondo Francesco e Franco Tagliarini. (1920-30). Ministry buildings. [Photograph] Archivio fotografico societa geografica Italiana. 
Goethe Institut. (2021). Lörcher's 1924-25 Ankara urban development. [Map] Başkentin Oluşumu: Avusturyalı, Alman ve Isviçreli mimarların izleri. Ankara: Goethe Institut. Retrieved from https://www.goethe.de/ins/tr/ank/prj/urs/arc/loe/trindex.htm

Hall, R. C. (2000). The Balkan wars, 1912-1913: Prelude to the first world war. London-New York: Routledge.

Hirst, P. Q. (2005). Space and power: politics, war and architecture. Cambridge: Polity.

Iaselli, L. (2004). L'espansione finanziaria dell'Italia in Albania (1925-1943). La Banca Nazionale d'Albania e la SVEA. Rivista di Storia Finanziaria (12), 65-104.

Iaselli, L. (2013). Le relazioni finanziarie tra Italia e Albania (1925-1943). Il ruolo della Banca Nazionale d'Albania. Paper presented at the L'Albania indipendente e le relazioni italo-albanesi (1912-2012), Atti del Convegno in occasione del centenario dell'indipendenza albanese, Roma.

İnönü Encyclopedia (1948). Ankara's plan of 1940. [Map] National Education Printing Press (Milli Eğitim Basımevi), Plates no.55, 56, 57.

Karaosmanoğlu, Y. K. (1934/2015). Ankara. İstanbul: İletişim.

Kezer, Z. (2015). Building modern Turkey: State, space, and ideology in the early republic. Pittsburgh, Pa.: University of Pittsburgh Press.

Kuban, D. (2016). Anadolu-Türk şehri, tarihi gelişmesi, sosyal ve fiziki özellikleri üzerine bazı gözlemler. In Sanat, mimarlı, toplum kültürü üzerine makaleler (pp. 40-67). İstanbul: Boyut Yayınları.

Madran, E. (2001). Gezi yapitlarında Ankara kenti ve yapıları. In Y. Yavuz (Ed.), Tarih içinde Ankara II (pp. 155-172). Ankara: ODTÜ Mimarlık Fakültesi Yayınları.

Miho, K. (2003). Shqipëria: vështrim urbanistik, 1912-1944. Tiranë: Extra.

Moricz, P. (1930). Kisebb közlemenyek: Utilevel Ankarabol. Turan XII, 37-39.

METU. (1924-25). Lörcher's Ankara plans 1924-25. [Map]. Ankara: METU Faculty of Architecture Library and Archives.

Posca, L. (2013). Architetti italiani in Albania (1914-1943). Roma: Clear.

Poujoulat, B. (1841). Voyage dans l'asie mineure, en mesopotamie, a palmyre, en syrie, en palestine et en egypte. Ducollet.

Rava, C. E. (1928). Dell'europeismo in architettura. Rassegna Italiana, 21(2), 133-140.

Rava, C. E. (1931). Di una architettura coloniale moderna. Domus, (42), 32-36.

Rava, C. E. (1941). Per la casa e la vita in colonia. Domus, (158), 61-63.

Resta, G. (2016). The Italian way: Urban planning heritage in Albania. Architecture and Urban Planning, (11), 19-23.

Resta, G. (2019). Atlante di progetti per l'Albania. La città e il territorio nel primo Novecento. Melfi: Libria.

Resta, G., \& Gatip, J. (2021). The aesthetic of right. How historical fake feeds populist agendas. IMG Journal, (4), 322-341.

Roselli, A. (2006). Italy and Albania: Financial relations in the fascist period. London-New York: I.B.Tauris.

Roth, J. (2014). Viaggio in Albania (V. Schweizer, Trans.). Bagno a Ripoli: Passigli. 
Roth, J. (2015). 35 ${ }^{\text {th }}$ chapter. In The hotel years. Wanderings in Europe between the wars. Granta Books. E-book.

Şahin Güçhan, N. (2001). 16-19 yy. nüfus tahminlerine göre Osmanlı Ankara'sında mahallelerin değişim süreçleri üzerine bir deneme. In Y. Yavuz (Ed.), Tarih içinde Ankara II (pp. 123-154). Ankara: ODTÜ Mimarlık Fakültesi Yayınları.

SALT Research. (1930). Republic square. [Photograph]. Postcard and photographs archive (AHANKA049). İstanbul.

SALT Research. (1930-40). Gazi Mustafa Kemal Boulevatrd. [Photograph]. Postcard and photographs archive (AHANKA131). İstanbul.

Sarıoğlu, M. (2001). Ankara bir modernleşme öyküsü (1919-1945). Ankara: T.C. Kültür Bakanlığı.

Şenol Cantek, F. (2011). 'Yaban'lar ve yerliler. Başkent olma sürecinde Ankara. İstanbul: İletişim.

Şimşir, B. N. (2006). Ankara... Ankara... bir başkentin doğuşu. Ankara: Bilgi Yayınevi.

Sözen, M. (1984). Cumhuriyet dönemi Türk mimarlı̆̆ı. Ankara: Türkiye İş Bankası Kültür Yayınları.

Tankut, G. (1993). Bir başkentin imarı: Ankara 1929-39. İstanbul: Anahtar Kitaplar Yayınevi.

Tankut, G. (2000). Jansen planı uygulama sorunları ve cumhuriyet demokrasisinin kent planına yaklaşımı. In Y. Tükel Yavuz (Ed.), Tarih içinde Ankara (pp. 301-316). Ankara: TBMM Basımevi.

Therborn, G. (2017). Cities of power. The urban, the national, the popular, the global. London, New York: Verso.

Türkyılmaz, M. (2015). Ankara'da havuzbaşları: 1923-1950/Ankara poolsides: 19231950. Journal of Ankara Studies, 3(1), 105-136.

VEKAM. (1927-28). Victory square. [Photograph]. Photograph and postcard archive (1017). Ankara: Vehbi Koç Ankara Studies Application and Research Center.

VEKAM. (1930). Nation square. [Photograph]. Photograph and postcard archive (1210). Ankara: Vehbi Koç Ankara Studies Application and Research Center.

Yarwood, J. (2011). Historical essay on Albania: urban planning of Tirana in the Zog period, Urban Planning in the Middle East: Case Studies (pp. 159-190). Newcastle upon Tyne: Cambridge Scholars Publishing.

\section{Notations}

Abbreviations

AQTN - Arkivi Qendror Teknik i Ndërtimit

UCEUA - Ufficio per l'Edilizia e l'Urbanistica d'Albania 